\title{
Influences of External Factors on Business Performance of Domestic Animal Feed Enterprises in Vietnam
}

\author{
Van Hau NGUYEN ${ }^{1}$, Thi Quynh Lien DUONG ${ }^{2}$, To Thi Huong QUYNH ${ }^{3}$, To Thi Thu TRANG ${ }^{4}$
}

Received: July 03, 2020 Revised: September 19, 2020 Accepted: October 05, 2020

\begin{abstract}
Vietnam is the country with the largest animal feed production in Southeast Asia. Domestic animal feed manufacturing enterprises play an important role in animal husbandry in particular and in agriculture in general. However, domestic animal feed enterprises in Vietnam are encountering shortcomings. This paper is conducted to investigate the impact levels of external determinants on business performance of domestic animal feed manufacturing enterprises, including: (i) policy and economic mechanism, (ii) supply-demand of animal feed products, and (iii) nature and level of market competition. We presented a research method, explaining the dependent variable 'business performance' and the independent variables. Data were collected from 120 questionnaires from domestic animal feed manufacturing enterprises. Based on these data, we use Cronbach's Alpha, EFA and run regression model for assessing the impact levels of each independent variable on the dependent variable of business performance of domestic animal feed manufacturing enterprises. The results show that three external determinants including (i) policy and economic mechanism, (ii) supply-demand of animal feed products, and (iii) nature and level of market competition, have positive relationships with business performance. Based on the findings, some recommendations are given for improving business performance of domestic animal feed manufacturing enterprises to ensure sustainability.
\end{abstract}

Keywords: External Factors, Business Performance, Animal Feed, Vietnam

JEL Classification Code: F65, G30, O16

\section{Introduction}

Domestic animal feed manufacturing enterprises play an important role in animal husbandry, in particular, and in agriculture, in general: (i) animal feed product is the main determinant of livestock production efficiency; (ii) contributing to promoting the agricultural restructure process

${ }^{1}$ First Author. Lecturer, Finance and Accounting 1 Department, Posts and Telecommunications Institute of Technology, Vietnam. Email: haunv@ptit.edu.vn

${ }^{2}$ Corresponding Author. Lecturer, Economics Department, Vinh University, Vietnam [Postal Address: No. 182, Le Duan Road, Vinh City, 113000, Vietnam] Email: quynhlien140679@gmail.com; quynhliendhv@gmail.com

${ }^{3}$ Lecturer, Construction Economics and Management Faculty - National University of Civil Engineering, Vietnam. Email: quynhtth@nuce.edu.vn

${ }^{4}$ Department of Accounting, University of Labor and Social Affairs,

Vietnam. Email: trang0312@gmail.com

(c) Copyright: The Author(s)

This is an Open Access article distributed under the terms of the Creative Commons Attribution Non-Commercial License (https://creativecommons.org/licenses/by-nc/4.0/) which permits unrestricted non-commercial use, distribution, and reproduction in any medium, provided the original work is properly cited. in the direction of industrialization and modernization; (iii) attracting domestic and foreign investment in the large amount, etc. However, domestic animal feed enterprises in Vietnam are encountering shortcomings, which affect business performance. For example, domestic animal feed businesses depend largely on imported raw materials, leading to high risks of price and exchange rate fluctuation. Besides, high commission rates of FDI enterprises for agents push domestic animal feed price up. In addition, with the dominant position in the animal feed market, FDI enterprises can set a price for those products more easily compared to other domestic businesses can. Moreover, under the pressure of the market, domestic animal feed enterprises have to constantly reduce the selling price of products while the price of input materials is high, resulting in business losses. Domestic feed production enterprises are currently underestimated in terms of production scale, distribution system as well as business management capacity (Dam, 2019).

Vietnam is the country with the largest animal feed production in Southeast Asia, with the published data in 2019, reaching approximately 20 million tons. Vietnam's animal feed market is growing and expanding, but opportunities 
and challenges for businesses of processing animal feed in a competitive environment are gradually high (Dam, 2019). According to the evaluation of the Ministry of Industry and Trade, compared to other countries in the region, animal feed price in Vietnam is always higher by about $15 \%$ to $20 \%$, which makes Vietnam's livestock products not strongly competitive yet.

According to a report by the Vietnam Department of Livestock Production, by the end of 2017, there were 147 domestic animal feed factories, mainly in the Red River Delta $(51 \%)$ and the Southeast region, Mekong River Delta $(39.5 \%)$. In particular, large capacity factories are more concentrated in the Red River Delta. Business performance or Operation Efficiency (OE) of enterprises is affected by several factors. Businesses must identify each factor, regularly analyze and assess the impact of factors in order to be able to adapt to external factors, perfect internal factors to continuously improve the operational efficiency of enterprises (Hoang, 2017). From the above reasons, it is necessary and meaningful to study the influence of external factors on the business performance of domestic animal feed enterprises.

\section{Literature Review}

The external factors affecting business performance have been a concern of researchers in Vietnam and in the world, focusing on three factors: (i) factors of policy and economic mechanism; (ii) factors of supply-demand of animal feed products, and (iii) factors of nature and level of market competition.

Zeitun and Tian (2007) conducted research on factors affecting business performance and market value of firms. Research data was conducted from 167 listed companies on the Amman, Jordan, Stock Exchange of 16 different business lines in the non-financial sector in the period 1989- 2003. The dependent variable 'business performance of an enterprise' is measured by the indicator 'return on total assets (ROA)'. The research results show that the operational efficiency of businesses in Jordan is greatly affected by the macro economy and regional environment. Dragnić (2014) analyzes changes of environmental factors as well as their impact on the efficiency of small and medium enterprises. The research result shows that three external factors affecting business performance of enterprises include: the overall state of the economy, the environment of the industry and customers.

Nguyen (2018) said that the legal environment was the state's regulations on procedures and issues related to the scope of business and production activities of firms, requiring each enterprise to participate in the environment where they need to research, learn and comply with those regulations. The legal environment consisted of six attributes: (i) the system of legal documents on accounting; (ii) system of tax legal documents; (iii) legal framework for business activities; (iv) business ethics and corporate social responsibility; (v) state management of business activities; and (vi) relationship between legal documents and the company's charter, rules and regulations. The author concludes that the legal environment has a significant impact on the business performance of animal feed enterprises. The fairness and rigor of the law at any level create an effect on the efficiency of business and production activities of enterprises.

Dam (2019) said that, in terms of macro management, the Government has had many policies to encourage the development of animal feed processing industry in recent years. In particular, the policy that has greatly affected this development is to encourage all economic sectors to invest in development and tax policy. Most of importing raw materials for animal feed that cannot be produced in the domestic market are taxed at $0 \%$. Nguyen et al. (2019) examined the impact of productivity in addition to the policy of increasing the foreign investors' ownership rate on the performance of businesses which were listed on Vietnam's stock exchange market from 2010 to 2017. With the database of 3.961 observations, the study employs a statistical method - multiple regression to estimate the relationship between labor productivity, foreign ownership as well as other firm-level characteristics and firm performance. Research findings show that increasing labor productivity and increasing foreign ownership rates help increase firm performance.

Nguyen and Khoa (2020) applied quantitative research methods with a survey of 350 seafood exporting enterprises in Kien Giang province to achieve the research objectives. The research results identified eleven key factors affecting the competitiveness of seafood exporting enterprises, including (1) vision and strategy of leader; (2) human resources management capability; (3) organization capability; (4) customer-responsive marketing capability; (5) relationship management capability; (6) technical capability; (7) competitors reaction capability; (8) business environment adoption capability; (9) financial capability; (10) products and services innovation capability; and (11) branding management. The research results provided the basis to propose some managerial implications to improve the competitiveness of exporting enterprises in the context of the global economic integration. Truong et al. (2020) used data of tourism firms in Hanoi during 2018-2019; the data used for analysis and regression consists of 135 observations, used Cronbach's Alpha, EFA and regression model to learn the effect of different variables on the Balanced scorecard application in evaluating the performance. The results show that two determinants, including internal factors of tourism firms (IF) and external factors of tourism firms (EF), had positive relationships with the Balanced scorecard application in evaluating the performance. 
The above analyses have identified main external factors that influence the business performance in firms in Vietnam. These studies use qualitative research methods and quantitative research methods, the scope of research on time from 2019 onwards. Beside, no research has been conducted so far to analyze and measure the impact of external factors influencing the business performance in domestic feedstuff processing firms in Vietnam. By inheriting those previous studies and selecting appropriate research methods, this research continues to expand and develop a new model to analyze, evaluate and measure the influence of external determinants on the business performance in domestic feedstuff processing firms in Vietnam.

\section{Research Methodology}

In order to achieve the objectives of this paper, we build on previous studies as well as the results of qualitative research through expert interviews and model analysis. Based on qualitative research results, we adjust and add observation variables to the questionnaire for conducting quantitative research. In the research data collected from January to June 2020, a questionnaire was sent to 150 financial managers and accountants working for domestic feedstuff processing firms. 105 questionnaires were collected and cleaned. All indicators are measured on the 5-point Likert scale, from 1 "without effect" to 5 "strongly". The questions were then entered into an SPSS file for analysis. Descriptive statistics were used to make an explicit of participants. Then, the SPSS22 was employed to analyze the impact level of factors and multi-group analysis, and done based on the financial managers and accountants viewpoint and analysis based on them judgment.

The research model is as follows:

Policy and economic mechanism (PEM) are measured by five items developed by Zeitun and Tian (2007); Dragnić (2014); Nguyen (2018); Dam (2019). The scales are measured on the 5-point Likert scale, from 1 "without effect" to 5 "strongly" (see Table 1).

As regards policies and mechanisms, it is undeniable that structural policies, investment policies, human resource training policies, science and technology policies are determining factors on business activities and operational efficiency of businesses. These macroeconomic policies and mechanisms either create priority or limit the development of enterprises. Policies and mechanisms can encourage businesses to invest to expand or narrow production and business activities. Economic policies and mechanisms are fundamental factors to create a business environment and have a great influence on businesses in the economy. A healthy business environment is also a basis for functional agencies to well forecast and properly regulate investment activities, to leave no industry or economic region in the situation of oversupply trend, to limit monopoly and to create a fair business environment among companies. Thus, policies and mechanisms are factors that encourage or discourage business activities, directly affect the results as well as the efficiency of production and business results of enterprises.

Supply-demand of animal feed products (SDAFP) is measured by three indicators proposed by Dragnić (2014). The scales are measured on the 5-point Likert scale, from 1 "without effect" to 5 "strongly" (see Table 1).

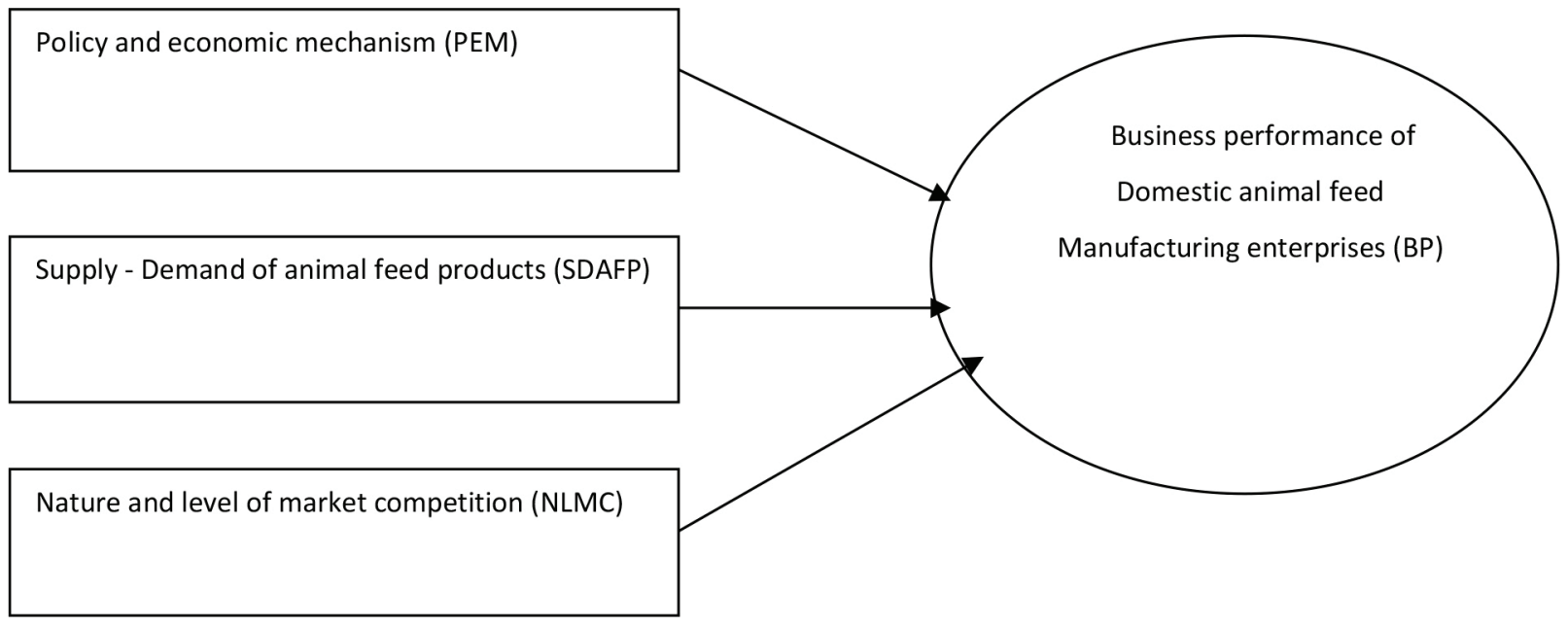

Figure 1: Research model 
Table 1: The independent variables are described

\begin{tabular}{|l|l|c|}
\hline Code & \multicolumn{1}{|c|}{ Scale } & Sources \\
\hline Policy and economic mechanism (PEM) & \multicolumn{1}{|c|}{ Zeitun \& Tian (2007), Dragnić (2014) } \\
\hline PEM1 & Macroeconomics & Nguyen (2018), Dam (2019) \\
\hline PEM2 & Regulatory environment & We propose \\
\hline PEM3 & Investment policy & We propose \\
\hline PEM4 & Human resource training policy & We propose \\
\hline PEM5 & Policy on science and technology. & Dragnić (2014) \\
\hline Supply - Demand of animal feed products (SDAFP) & We propose \\
\hline SDAFP1 & Customers & We propose \\
\hline SDAFP2 & Animal feed consumption of the market & We propose \\
\hline SDAFP3 & Price of animal feed in the market & We propose \\
\hline Nature and level of market competition (NLMC) & \begin{tabular}{l}
$\mid$ \\
\hline NLMC1
\end{tabular} & $\begin{array}{l}\text { Enterprises improve the quality of } \\
\text { animal feed products }\end{array}$ \\
\hline NLMC2 & $\begin{array}{l}\text { Businesses enhance goods quality } \\
\text { warranty }\end{array}$ & We propose \\
\hline NLMC3 & $\begin{array}{l}\text { Competition in the production and } \\
\text { consumption of substitutes }\end{array}$ &
\end{tabular}

Supply and demand link the beginning and the ending of reproduction process, which is the relationship between production and consumption. At the same time, the supply and demand relationship also shows the relationship of interests between producers and consumers, between sellers and buyers. Supply-demand of goods has a direct impact on businesses through the degree of goods consumption and market prices. If the demand for goods increases, it will help businesses sell more products at a favorable price, leading to an increase in profit for businesses, thereby, businesses will have accumulated resources to continue investing to expand production and business activities. Conversely, if supply is greater than demand, it will be difficult for goods to be consumed, which means inventories will soar. Besides, when the supply is greater than the demand, the goods and services price will fall, businesses have no choice, but reduce their selling price to lower their inventory to avoid damage and reduction in the quality of goods in the storage process. Along with that, businesses also have to narrow the production scale to reduce supply, which also has a great impact on their operational efficiency.

Nature and level of market competition (NLMC) consists of three items. We propose all three scales. The scales are measured on the 5-point Likert scale, from 1 "without effect" to 5 "strongly" (see Table 1).

The level of competition among enterprises in the industry is an important factor that creates either opportunities or threats for businesses. If the competition level is low, businesses have the opportunity to earn higher profits. Whereas, if the competition is fierce and harsh in all aspects (product quality, replacement products, prices, etc.), there will be a risk of profit decrease of enterprises. Competition is manifested through reducing prices, improving goods and services quality and quality warranty. Therefore, in a certain perspective, competition has a good impact as a boost for businesses to upgrade techniques, streamline production, change models, improve productivity and product quality and lower product costs. The competition level between enterprises in the same industry directly affects the supplied amount of goods of each enterprise. Thereby, it will affect the operational efficiency of enterprises.

Competition in substitutes production and consumption has a significant impact on the results and operational efficiency of a business. It can reduce the primary goods consumption and products and limit the possible setting price. Thus, it will limit the profitability of the business. Conversely, if an enterprise's product does not have or has very few alternatives, it has the opportunity to sell that product at a favorable price and obtain additional profits. Business performance of domestic animal feed manufacturing enterprises (BP) consisted of six attributes (Nguyen, 2018). 


\section{Results}

\subsection{Descriptive Statistics}

Information on data collected is shown in Table 2 . It shows that, among the 105 respondents, about $35.2 \%$ were male, while the remaining $68(64.8 \%)$ were female; out the 105 respondents, $14(13.3 \%)$ are Chief financial officer (CFO), 45 (42.9\%) are General accountants, $24(22.9 \%)$ are deputy HR manager of human resources department, $22.2 \%$ of the participants are Chief accountants and $22(21.0 \%)$ are Deputy CFO. Of these, $68(64.8 \%)$ respondents had working experience of over 5 years and $35.2 \%$ participants had working experience of from 1 to 5 years.

\subsection{Results of Quality Scale Analysis}

Using scale analysis can eliminate inconsistent variables and reduce errors in the research model. Therefore, only variables, which have total correlation coefficients (Corrected Item - Total Correlation) greater than 0.3 and Cronbach's Alpha coefficients equal or greater than 0.6 are accepted (Hair et al. 2009; Hoang \& Chu, 2008). Cronbach's Alpha analysis of determinants has shown their influence on business performance of domestic animal feed manufacturing enterprises (three determinants with 11 observed variables) and the result is presented in Table 3 . The result shows that all Cronbach's Alpha coefficients of population are above 0.6; all Corrected Item - Total Correlation of observed variables are above 0.3. But PEM3 is excluded (Cronbach's Alpha

Table 2: Respondent Characteristics

\begin{tabular}{|c|c|c|c|}
\hline & Frequency & Percent & $\begin{array}{c}\text { Cumulative } \\
\text { percent }\end{array}$ \\
\hline \multicolumn{4}{|l|}{ Gender } \\
\hline Male & 37 & 35.2 & 35.2 \\
\hline Female & 68 & 64.8 & 100.0 \\
\hline \multicolumn{4}{|l|}{ Job description } \\
\hline $\begin{array}{l}\text { Chief financial } \\
\text { officer (CFO) }\end{array}$ & 14 & 13.3 & 13.3 \\
\hline $\begin{array}{l}\text { General } \\
\text { accountants }\end{array}$ & 45 & 42.9 & 56.2 \\
\hline $\begin{array}{l}\text { Chief } \\
\text { accountants }\end{array}$ & 24 & 22.9 & 79.0 \\
\hline Deputy CFO & 22 & 21.0 & 100.0 \\
\hline \multicolumn{4}{|c|}{ Work experience } \\
\hline Over 5 years & 68 & 64.8 & 64.8 \\
\hline To 5 years & 37 & 35.2 & 100.0 \\
\hline Total & 105 & 100 & \\
\hline
\end{tabular}

coefficient is $0.768>0.767)$. So, 10 variables of research model are suitable for next analyses (Hair et al, 2006).

\subsection{Exploratory Factor Analysis}

EFA was conducted and we used the method of extracting coefficients. The results of Component Analysis and Varimax Analyzes yields 10 attributes for the independent variables. The results of factor analysis in Table 4 show that $0.5<\mathrm{KMO}$ $=0.709<1$. Bartlett's testimony shows sig. $=0.000<0.05$. It means variables in the whole are interrelated.

After implementing the rotation matrix, three determinants have factor loading greater than 0.5 and Eigenvalues greater than 1; the variance explained is $72.573 \%$, which demonstrates that research data analyzing factor discovery is appropriate. Through the quality assurance of the scale and the test of the EFA model, we have identified three determinants influencing on business performance of domestic animal feed manufacturing enterprises.

\subsection{Regression Model Analysis}

Based on adjusted model after the exploratory factor analysis, we have the following multiple regression model:

$$
\mathrm{BP}=\alpha+\beta_{1} \mathrm{PEM}+\beta_{2} \mathrm{SDAFP}+\beta_{3} \mathrm{NLMC}
$$

Results of Table 5, 6, 7 show the following:

Multicollinearity testing: all variance inflation factors (VIF) of independent variables are under 2, so multicollinearity of model is low (Hair et al. 2009, Hoang \& Chu, 2008). Therefore, this regression model does not have any violation of the CLRM basic assumption. Durbin-Watson statistic, which is used to test the autocorrelation of residuals presents the model does not violate when using multiple regression method because Durbin-Watson value is 1.603 (in the interval of 1 and $3)$. In other words, the model indicated no autocorrelation of residuals (Hair et al. 2009, Hoang \& Chu, 2008).

ANOVA testing result: level of significant (Sig.) $=0.000$ implies that multiple regression model is suitable with data. Coefficient of $\mathrm{R}^{2}$ ( $\mathrm{R}$ Square) $=0.559$, which means $55.9 \%$ of the total variation in the business performance of domestic animal feed manufacturing enterprises will be explained by the regression model.

Research model result indicates that all independent variables, namely, policy and economic mechanism (PEM), supply-demand of animal feed products (SDAFP), and nature and level of market competition (NLMC) are significant (because Sig. $<0.05$ ) to business performance of domestic animal feed manufacturing enterprises. Determinants have influences on business performance of domestic animal feed manufacturing enterprises are presented in the following standardized regression model:

$$
\mathrm{BP}=0.590 \times \mathrm{PEM}+0.321 \times \mathrm{SDAFP}+0.124 \times \mathrm{NLMC}
$$


Table 3: Results of Determinants Scales in the Model

\begin{tabular}{|c|c|c|c|c|}
\hline & $\begin{array}{l}\text { Scale Mean if } \\
\text { Item Deleted }\end{array}$ & $\begin{array}{l}\text { Scale Variance if } \\
\text { Item Deleted }\end{array}$ & $\begin{array}{l}\text { Corrected Item- } \\
\text { Total Correlation }\end{array}$ & $\begin{array}{l}\text { Cronbach's Alpha if } \\
\text { Item Deleted }\end{array}$ \\
\hline \multicolumn{5}{|c|}{ Policy and economic mechanism (PEM): Cronbach's Alpha: .767 } \\
\hline PEM1 & 14.190 & 7.252 & .623 & .692 \\
\hline PEM2 & 13.990 & 7.702 & .599 & .703 \\
\hline PEM3 & 14.438 & 8.152 & .421 & .768 \\
\hline PEM4 & 14.010 & 8.317 & .525 & .729 \\
\hline PEM5 & 14.114 & 8.256 & .536 & .726 \\
\hline \multicolumn{5}{|c|}{ Supply - Demand of animal feed products (SDAFP): Cronbach's Alpha: .827 } \\
\hline SDAFP1 & 7.295 & 2.806 & .624 & .822 \\
\hline SDAFP2 & 7.295 & 2.672 & .713 & .734 \\
\hline SDAFP3 & 7.295 & 2.595 & .720 & .726 \\
\hline \multicolumn{5}{|c|}{ Nature and level of market competition (NLMC): Cronbach's Alpha: .896 } \\
\hline NLMC1 & 7.79 & 1.648 & .869 & .791 \\
\hline NLMC2 & 7.73 & 1.851 & .644 & .979 \\
\hline NLMC3 & 7.77 & 1.543 & .892 & .765 \\
\hline
\end{tabular}

Table 4: KMO and Bartlett's Test

\begin{tabular}{|l|l|c|}
\hline \multicolumn{2}{|l|}{$\begin{array}{l}\text { Kaiser-Meyer-Olkin Measure of Sampling } \\
\text { Adequacy. }\end{array}$} & .709 \\
\hline $\begin{array}{l}\text { Bartlett's Test of } \\
\text { Sphericity }\end{array}$ & Approx. Chi-Square & 644.204 \\
\cline { 2 - 3 } & Df & 45 \\
\cline { 2 - 3 } & Sig. & 0.000 \\
\hline
\end{tabular}

Table 5: Model Summary ${ }^{b}$

\begin{tabular}{|l|c|c|c|c|c|}
\hline Model & $\mathbf{R}$ & $\begin{array}{c}\mathbf{R} \\
\text { Square }\end{array}$ & $\begin{array}{c}\text { Adjusted } \\
\mathbf{R} \\
\text { Square }\end{array}$ & $\begin{array}{c}\text { Std. } \\
\text { Error } \\
\text { of the } \\
\text { Estimate }\end{array}$ & $\begin{array}{c}\text { Durbin- } \\
\text { Watson }\end{array}$ \\
\hline 1 & $.748^{a}$ & .559 & 0.546 & .40297 & 1.603 \\
\hline
\end{tabular}

a. Predictors (Constant): PEM, NLMC, SDAFP

b. Dependent Variable: BP

Table 6: Anova ${ }^{a}$

\begin{tabular}{|l|c|c|c|c|c|}
\hline Model & Sum of Squares & Df & $\begin{array}{c}\text { Mean } \\
\text { Square }\end{array}$ & F \\
\hline 1 Regression & 20.793 & 3 & 6.931 & 42.683 \\
\hline Residual & 16.401 & 101 & .162 & $.000^{\mathrm{b}}$ \\
\hline Total & 37.194 & 104 & & \\
\hline
\end{tabular}

a. Dependent Variable: BP

b. Predictors: (Constant): PEM, NLMC, SDAFP

Table 7: Coefficients ${ }^{a}$

\begin{tabular}{|l|c|c|c|c|c|c|c|}
\hline \multirow{2}{*}{ Model } & \multicolumn{2}{|c|}{$\begin{array}{c}\text { Unstandardized } \\
\text { Coefficients }\end{array}$} & \multirow{2}{*}{$\begin{array}{c}\text { Standardized } \\
\text { Coefficients }\end{array}$} & \multirow{2}{*}{ T } & \multirow{2}{*}{ Sig. } & \multicolumn{2}{|c|}{$\begin{array}{c}\text { Collinearity } \\
\text { Statistics }\end{array}$} \\
\cline { 2 - 8 } & B & $\begin{array}{c}\text { Std. } \\
\text { Error }\end{array}$ & Beta & & & VIF \\
\hline (Constant) & 2.788 & .383 & & 7.284 & .000 & & \\
\hline PEM & .495 & .056 & .590 & 8.884 & .000 & .982 & 1.018 \\
\hline SDAFP & .245 & .060 & .321 & 4.106 & .000 & .709 & 1.410 \\
\hline NLMC & .114 & .072 & .124 & 1.586 & .016 & .718 & 1.392 \\
\hline
\end{tabular}

a. Dependent Variable: BP 


\section{Discussion and Management Implication}

\subsection{Policy and Economic Mechanism}

The development of domestic animal feed enterprises also affects the ecological environment and public health. Business performance of animal feed enterprises has an influence on breeders. The quality of animal feed is one of the factors affecting the ecological environment, food hygiene and safety and the health of people using livestock products. Therefore, the State is required to have reasonable investment policies for research and development, and appropriate application of scientific advances to production, and have an appropriate macro management mechanism to ensure the sustainable development of domestic animal feed enterprises, that is consistent with the objectives of socioeconomic development.

The Government has issued Decree No. 39/2017 / ND-CP on the management of animal and aqua feeds (Government, 2017). The State encourages all economic and social sectors to invest in research, training, industrial promotion, agricultural extension, and transfer of scientific and technological advances in nutrition and animal feed process. Feed manufacturing enterprises can sell their products to customers who are farmers, farms, intermediaries and so on.

The business development of animal feed enterprises must comply with the regulations of the Government and the Ministry of Agriculture and Rural Development: (i) manufacturing and processing locations must be located in areas that are not polluted by factors such as waste, toxic chemicals, animal husbandry, and aquaculture; (ii) the production area must have walls, barriers that separate it from the outside; (iii) having an environmental impact assessment report or environmental protection plan that are in accordance with the law on environment; (iv) requirements on workshops and equipment; (v) the person in charge of engineering must have a university or higher degree in one of the fields of animal husbandry, animal husbandryveterinary medicine, veterinary medicine, food technology, biotechnology (for animal feeds ) or major in aquaculture, biology, food technology (for aquaculture feeds); (vi) having or hiring laboratories to analyze the quality of animal and aqua feeds in the process of manufacturing and processing.

The reality shows that economic policies and mechanisms have a great impact on the operational efficiency of an enterprise, which can lead to the dissolution of an enterprise when it fails to meet regulatory requirements of the State, as well as reduce the efficiency of enterprises when strict conditions that enterprises have to comply are laid down, leading to accelerating costs of businesses. On the other hand, it is also possible to protect and facilitate some enterprises to take advantage of opportunities created by economic policies and mechanisms.
Currently, the economic policy and mechanism in the animal feed industry is open for enterprises to compete freely, so they need to take advantage of opportunities, focus on fulfilling their production and business tasks; invest to improve product quality, do research and apply new, safe and beneficial products to consumers' health and environmentally friendly products; focus on investment in material production facilities, avoiding import dependence as they are at present.

The Chairman of Hanoi People's Committee shared the difficulties faced by animal feed enterprises in recent time, especially from the impact of African swine cholera and COVID-19; at the same time, required that localities that have animal feed production enterprises support tight control of epidemic prevention; ensured essential conditions such as electricity and water so that enterprises can be assured to keep manufacturing. Hanoi City will create favorable conditions for animal feed enterprises to expand production and access to preferential loans, to re-breed and develop herds. The city will also propose the Government, ministries, and branches to consider reducing the import tax on production materials, and create favorable conditions in transporting and circulating goods from ports to factories, from factories to agents and husbandry bran. In the coming days, the city will work with animal feed enterprises to solve difficulties and obstacles, facilitate the re-breeding and development of herds in the area (Minh Van, 2020).

In order to promote positive effects, as well as minimize negative impacts of economic policy and mechanism factors on operational efficiency of animal feed enterprises, the state functional agencies must regularly improve and complete the policies and mechanisms; the animal feed enterprises must carefully study economic policies and mechanisms before conducting production and business activities. Only by studying and understanding economic conditions and the State's policies can enterprises avoid legal violations, make good use of incentives in economic policies. This is the basis for enterprises to develop in the beneficial direction that improves operational efficiency and develops enerprises in a sustainable manner.

\subsection{Supply-Demand of Animal Feed Products}

2019 was a difficult year for the livestock industry due to the impact of the African swine cholera, which resulted in a sharp reduction of the country's total pig herds and the demand for animal feed products. However, the import of feed and materials has only decreased slightly because the domestic livestock industry is increasingly dependent on the import market. According to data from the General Department of Customs, in the first 11 months of 2019, Vietnam spent more than US $\$ 3.3$ billion on importing feed and materials, reducing only $4 \%$ over the same period (Binh Nguyen, 2020). 
The main import markets of Vietnam's animal feed materials are the United States, South America, the EU, and Russia, which are heavily affected by the COVID-19 pandemic, almost paralyzing trade and logistics systems. The COVID-19 pandemic is making the shipping and road transportation extremely difficult as the disease control is conducted strictly in exporting countries, not to mention there are many countries that have closed their borders. In the near future, if the COVID-19 pandemic does not decline, the import of corn, soybean meal, feed additives will certainly be more difficult. Therefore, the scenario of a shortage of raw materials for feed industry in the next three months is entirely predicted.

When Vietnam actively participates in the integration, the competition of the whole market makes the investment of enterprises as well as the difference in feed prices between the world and Vietnam market smaller. The reason is that the import tax is reduced when the trade agreements are in effect; and the competition in this industry also contributes to more stability of the market. However, the import turnover of feed ingredients has been constantly increasing over the years (Binh Nguyen, 2020).

The current increase in pig prices is due to scarcity of supplies and raw material prices. The source of raw materials and animal feed for pigs in the world is corn and soybean meal. As a result, when the price of pigs increases, so do corn and soybeans.

Enterprises all have a closed production technology process, input raw materials are raw materials (fish meal, bone meal, soybean meal, bran, plates) and other raw materials (antibiotics , micronutrients, plant protection, and so on), the output is the complete industrial animal feed products, mainly in two forms: pellets and concentrated bran.

In order to minimize the negative effects of the law of supply and demand, the authorities need to have a plan for the development of the feed industry, with appropriate and effective policies and regulatory measures to establish and maintain the balance between supply and demand of animal feed products. On the side of animal feed enterprises, when conducting production and business activities, they must conduct a thorough investigation and study of market demands for animal feed products to establish a production and business plan, choose an appropriate production and business scale and avoid spreading investment, producing rampant feed products, exceeding market demand. This will help enterprises avoid negative effects of the law of supplydemand on business efficiency of enterprises.

\subsection{Nature and Level of Market Competition}

As of 2014, Vietnam's animal feed market was still at a disadvantage for domestic enterprises when CP Vietnam Livestock Joint Stock Company took the leading position with $18.8 \%$ of market share, then followed by Proconco (Vietnam-
France joint venture) that holds $10.8 \%$ and Cagrill Vietnam that holds $6.7 \%$. Out of 10 animal feed manufacturing enterprises that have the largest market share in the country, only Dabaco Vietnam Group and Vina Corporation are Vietnamese enterprises with modest market share of 3\% and $2 \%$, respectively. Domestic animal feed enterprises are now evaluated as weak in terms of production scale, distribution system as well as business management capacity. However, by 2015 and 2016, this market witnessed many investments from Vietnamese enterprises, which changed the situation. The most notable one is the acquisition of Masan Group and the birth of Masan Nutri Science (MNS). Almost immediately after its establishment, MNS held a $14 \%$ market share of the industry, ranking second after CP Vietnam.

Currently, some domestic animal feed manufacturing enterprises have the leading market shares in the bloc, such as Masan Nutri-Science (MNS) of Masan Group, which directly runs two companies, Proconco and ANCO; DABACO Group Joint Stock Company; and Hong Ha Nutrition Joint Stock Company. Although being dominant in terms of output and operating capacity, domestic enterprises are in weak position compared to FDI enterprises. Especially in the difficult context of the livestock industry, many domestic enterprises in the field have to narrow down operating capacity and market share. Although the market is forecast to increase sales year by year, in the past two years, the raising of cattle, poultry and aquatic products has always fluctuated in a downward trend. This has greatly affected the business situation of animal feed production enterprises, leading to fierce competition between two blocks of internal and external enterprises. In addition, some businesses such as ANCO, Hung Vuong, and Proconco are also minimizing the costs of good sold, increasing competitiveness, especially through the price compared to FDI rivals by direct sales to livestock farmers without distributors (Thao Duong, 2017).

The animal feed industry is also the industry that is in the most extensive international integration, with over 65 countries and territories exchanging and trading the most modern and latest animal feed technology, equipment, and materials. Vietnam's market welcomes almost all major and well-known animal feed companies in the world; information on domestic material prices is in daily connection to major material trading centers in the world such as America, Europe (Huyen Trang, 2018).

The unequal distribution of feed manufacturing factories, where factories are mainly located in the Red River Delta, the Southeast and the Mekong River Delta, has caused an unreasonable situation. In isolated and remote areas, the price of livestock products is lower, but the feed price is higher and the quality of feed is often not guaranteed. These areas are mostly the market segment of small companies, and outsourcing companies (animal feed products transported to the northwestern provinces can cost from 700 to $800 \mathrm{VND} /$ freight) (Huyen Trang, 2018). 
The competition forces animal feed enterprises to produce and supply the feed products that the market needs to meet the increasingly diverse needs of customers and breeders. In order to do so, each animal feed enterprise must improve the quality of animal feed products by constantly applying scientific and technical advances into its business and production activities. Besides, there must be measures to optimize the inputs of production in order to maximizing production and business results.

\section{References}

Binh Nguyen (2020). Breeding faces 'storms', the trade deficit of feed ingredients is still large. Retrieved January 10, 2020 from: http://baodongnai.com.vn/kinhte/202001/chan-nuoi-gap-baonhap-sieu-nguyen-lieu-thuc-an-van-lon-2982798/.

Dam, P. L. (2019). Activity based costing accounting in domestic feedstuff processing enterprises. $\mathrm{PhD}$ Thesis. Nationnal Economics University, Hanoi, Vietnam.

Dragnić, D. (2014). Impact of Internal and External factors on the performance of fast-growing small and medium business. Management - Journal of Contemporary Management Issues, 19(1), 119-159.

Government (2017). Decree No. 39/2017 / ND-CP on the management of animal and aqua feeds; April 4, 2017.

Hair, J. F., Anderson, R. E., Tatham, R. L., \& Black, W. C. (2006). Multivariate data analysis. Upper Saddle River, NJ: PrenticeHall International Inc.

Hair, J. F., Black, W. C., Babin, B. J., \& Anderson, R. E. (2009). Multivariate Data Analysis (7th ed.). Upper Saddle River, NJ: Prentice Hall International.

Hoang, Q. M. (2017). Study of factors affecting business performance of industrial explosive material enterprises in
Vietnam. Doctoral Thesis. National Economics University, Hanoi, Vietnam.

Hoang, T., \& Chu, N. M. N. (2008). Analyzing researched data with SPSS ( $2^{\text {nd }}$ ed.). Ho Chi Minh City, Vietnam: Hong Duc Publishing House.

Huyen Trang (2018). Vietnam animal feed market. Retrieved October 3, 2018, from: http://nhachannuoi.vn/thi-truong-thucan-chan-nuoi-viet-nam/.

Minh Van (2020). Supporting facilities for animal feed production. Retrieved July 7, 2020 from: https://nhandan.com.vn/tranghanoitin-chung/ho-tro-cac-co-so-san-xuat-thuc-an-chan-nuoi-456274/.

Nguyen, T. T. (2018). Impacts of the legal environment on business performance of animal feed enterprises in Vietnam. The Joural Accounting and Auditing, 6, 45-49. [Vietnamese]

Nguyen, M. T., \& Khoa, B. T. (2019). Improving the Competitiveness of Exporting Enterprises: A Case of Kien Giang Province in Vietnam. Journal of Asian Finance, Economics and Business, 7(6), 495-508. https://doi.org/10.13106/jafeb.2020.vol7.no6.495.

Nguyen, P. A., Nguyen, A. H., Ngo, T. P., \& Nguyen, P. V. (2019). The Relationship between Productivity and Firm's Performance: Evidence from Listed Firms in Vietnam Stock Exchange. Journal of Asian Finance, Economics and Business, 6(3), 131140. https://doi.org/10.13106/jafeb.2019.vol6.no3.131.

Thao Duong (2017). Animal feed market: Intense competition. Retrieved December 17, 2019 from: https://congthuong.vn/thitruong-thuc-an-chan-nuoi-canh-tranh-gay-gat-96882.html.

Truong, D. D., Nguyen, H., \& Duong, T. Q. L. (2020). Factors Influencing Balanced Scorecard Application in Evaluating the Performance of Tourist Firms. Journal of Asian Finance, Economics and Business, 7(5), 217-224. DOI:https://doi. org/10.13106/jafeb.2020.vol7.no5.217.

Zeitun, R., \& Tian, G. G. (2007): Capital structure and corporate performance: evidence from Jordan. Australasian Accounting Business and Finance Journal, 1(4), 40-61. 